\title{
Study on Pursuing the Criticalness of the Ideological and Political Theory Course in Colleges and Universities
}

\author{
Yu Haiyan ${ }^{1, a}$ \\ ${ }^{1}$ School of Marxism, Anhui Vocational and Technical College, Hefei, Anhui, 230011 \\ a9179990@qq.com
}

\begin{abstract}
The theme of facilitating positive energy has always been involved in the ideological and political theory course for a long time, while there is little criticism of wrong thoughts and views. However, it is necessary and imperative to adhere to the criticalness of the ideological and political theory course. To this end, not only should a direct and clear-cut stand be taken in face of various wrong thoughts and views, but also a critical reflection on the historical and practical problems of the ideological and political theory course should be conducted. As far as the need of being critical for such course is concerned, the following aspects needs to be taken into account: first of all, adhering to criticalness is an important feature of the Marxist theory; secondly, sticking to criticalness entails the direct and rational criticism of all kinds of wrong thoughts and ensures the dominant position of the classroom; finally, it also requires the active participation of the faculty of this course so as to improve their critical and constructive ability.
\end{abstract}

Keywords: ideological and political theory course, criticalness

\section{INTRODUCTION}

"Adhere to the consistency of constructiveness and criticalness; deliver mainstream ideology; confront all kinds of wrong thoughts and ideological trends." [1] This is one of the requirements clearly put forward by General Secretary Xi Jinping in 318 Teachers' Symposium for Ideological and Political Studies, in which the value orientation and fundamental principles have been clearly stated. For a long time, the ideological and political theory course in colleges and universities mainly focuses on the good side in the process of teaching, while the criticism of wrong ideas and trends of thought has been rarely dealt with. In fact, not only should positive education be carried out, but also negative education should be included. That is to say, teachers must dare to "show the sword" which means boldly abandoning wrong ideas and trends and also be good at that. By doing so, the teachers can help students distinguish right from wrong, good and evil, beauty and ugliness so that the students can be firm in their ideals and convictions and equip themselves with the "four self-confidences".

\section{AN IMPORTANT THEORETICAL QUALITY OF MARXISM -- ADHERENCE TO CRITICALNESS}

The nature of being critical and revolutionary is an important theoretical quality of Marxism. Today, in the ideological and political class of colleges and universities, we cherish the great achievements of Marx and we cannot ignore and forget this important theoretical feature of the Marxist theory.

\subsection{Marxism itself is Developed on the Basis of Criticizing and Inheriting Predecessors, Thoughts}

Marxism is formed and developed on the basis of criticizing and surpassing the previous ideological and theoretical achievements. Many of Marx's works are full of critical spirit. The process of Marx and Engels establishing the scientific world outlook is the process of constantly fighting against all kinds of wrong ideas. They thoroughly criticized Hegel's idealism, Feuerbach's half materialism, and utopian socialism. Until The Communist Manifesto was published in 1848, the scientific world outlook finally came into being. 
"Philosophy and social sciences should have critical spirit, which is the most valuable spiritual quality of Marxism." [2] Similarly, in the theoretical process of the localization of Marxism in China, including socialist revolutionary and construction thoughts, all of the ideologists dare to expose wrong ideas and trends of thought, highlighting the spirit of criticism. Teachers of the ideological and political theory course in colleges and universities need to make clear the theoretical achievements of the localization of Marxism in China, and need to distinguish the boundaries between truth and falsehood, between Marxism and wrong ideas for students in the classroom.

\subsection{The Development History of Marxism equal to the History of Criticism}

From the day of its birth, Marxism has begun to criticize capitalism and all kinds of utopian socialist thoughts. The same is true as the introduction of Marxism into China. In the course of one hundred years of Party history, the Chinese Communists have never forgotten to carry out all kinds of struggles. During the period of democratic revolution, Mao Zedong once pointed out, "Fighting against wrong ideas is like vaccination against cowpox. After taking the vaccine, people's immunity will be enhanced. What is cultivated in the greenhouse will not have strong vitality." [3]232 "Communists should ask why for everything. They should think carefully in their own minds to see if it is realistic and reasonable. They should never follow blindly or advocate slavishness." ${ }^{[4]} 827$ It is precisely this kind of thought and attitude of seeking truth from facts and never blindly following that enabled the Chinese revolutionists to criticize and overcome all kinds of "Left" and "Right" mistakes and find the right path for China's national conditions. During the period of reform and opening up, the second generation of the Party's collective leadership with Deng Xiaoping as the main representative, under the international background of socialism falling into a low ebb and communism weakening, strongly opposed the bourgeois liberalization trend of thought and successfully created a new road of socialist construction with Chinese characteristics. By summing up the historical experience and lessons since the founding of the People's Republic of China, Deng Xiaoping pointed out, "we can no longer follow the old road or engage in any political movement, but we must master the weapon of criticism." [5]391 After the deepening of reform and opening up, Deng further pointed out, "After the opening up, some decadent things have come in, and ugly phenomena have also appeared in some parts of China, such as drug abuse, prostitution, economic crimes, etc. We should pay attention to them, resolutely ban and crack down on them, and never allow them to grow." [6]379 Entering the new era, China is rising in an all-round way and is increasingly moving towards the center of the world stage. General Secretary $\mathrm{Xi}$ Jinping has been emphasizing the importance of struggle in the ideological field. He stressed, "to do well in propaganda and ideological work under the new situation, we must consciously assume the mission of raising the banner, gathering people's hearts, cultivating new talents, promoting culture and developing the national image. This requires us to continue to pay attention to various social trends of thought, and to evaluate, criticize and rectify the wrong social trends of thought." [7] From this, we can see clearly that the struggle against all kinds of wrong thoughts will be a long-term process. As a teacher of the ideological and political theory course in colleges and universities, we must bravely shoulder the mission, consciously establish the consciousness of criticism, fully use the weapon of criticism, and effectively impart the theory of criticism.

\section{VALUE THE MAIN CHANNEL OF CLASSROOMS AND CRITICIZE VARIOUS WRONG THOUGHTS IN A DIRECT AND RATIONAL WAY}

"If you want to destroy a country, you must first destroy its history." The disintegration of the Soviet Union and the drastic changes in Eastern Europe show that the collapse of countries and the loss of political power often start from the ideological field. The ideological and political theory course in colleges and universities must correctly understand and treat all kinds of current social thoughts, focus on the main channel of classrooms, educate and guide students to build up their ideals and beliefs, promote the truth, the good and the beauty, and denounce the fake, the evil and the ugly.

\subsection{Criticize Historical Nihilism Directly with Reason}

For some time, some spoofs and videos about revolutionary leaders, national heroes and patriots have been widely spread in various forums, blogs, microblogs, WeChat and We-Media platforms. For example, some ridiculous jokes have emerged on some platforms: it is impossible that Huang Jiguang's chest can resist the gun fire and that Qiu Shaoyun can stay still in the fire. There are also some spoofs on Lei Feng and jokes about "Far away from Liu Hulan". The essence of these spoofs and jokes is historical nihilism. Such erroneous ideological trends as slandering historical figures, distorting the party's history, attempting to negate the party's leadership, Marxism and socialism with Chinese characteristics must be firmly resisted. Teenagers are in the period of values formation. They are far away from the historical era, and their understanding of history of the Communist Party of China, the People's Republic of China, reform and opening-up as well as socialism is not comprehensive and profound enough. They tend to see the so-called eye-catching new ideas and are easy to feel confused, thus offsetting the red patriotic education they have received. In this context, if the teachers do not stand 
firm, dare not face up to all kinds of wrong ideas and behavior, and let historical nihilism overflow freely in the ideological and political theory class in colleges and universities, it is bound to have a negative impact on young people's conscience and moral bottom line. Therefore, the teachers of ideological and political theory course in colleges and universities must take up the weapon of criticism and directly point out that the core of historical nihilism is to fundamentally disturb people's minds, deny the basic facts, and negate the rationality and legitimacy of the ruling of the Communist Party of China.

\subsection{Criticize the Theory of Universal Values Directly with Reason}

Why should we righteously criticize the theory of "Universal Values"? Some people may think that the democracy, freedom and human rights advocated by Western countries are also what we promote. This requires the teachers of ideological and political theory course to reveal the real face of the so-called "Universal Values" in the West. Taking COVID-19 as an example, we can clearly see that in Western countries, especially in the United States, when dealing with the epidemic, whether their value choice is "capital first" or "people first", in other words, "life first" or "election first". The so-called "equality" and "human rights" are powerless in the face of the virus. Therefore, the purpose of the West to promote "Universal Values" is to promote the so-called concept of political democracy and governance model, so as to achieve the purpose of gross interference in other countries' internal affairs, differentiation and westernization. Throughout history, the West has been interfering in the internal affairs of other countries under the banner of "Universal Values", but the long-standing problems of racial discrimination, gender discrimination, labor and capital antagonism in their own countries have not been effectively solved. What they cover up under the guise of "Universal Values" is plunder and disaster. Looking back on the humiliating history of the Chinese nation in the past one hundred years, all kinds of cessions and reparations and signing various unequal treaties all embody the bloody plundering nature of Western countries. Since the 18th National Congress of the Communist Party of China, China's all-round rise has become the focus of attention of all countries in the world. Western countries led by the United States suddenly feel that China has not been westernized but has become a powerful competitor. As a result, the Western countries constantly use "Universal Values" as a cover to intervene in China's internal affairs. For instance, the turmoil in Hong Kong was a deliberate plot by the United States under the pretext of "human rights" and "democracy", but it was claimed to be a "beautiful scenery" by the United States. A spokesman for the Ministry of Foreign Affairs severely fought back. In the face of COVID-19, the United States once again took the "human rights" and "freedom" as a pretext to assert that China's measures such as city closures and home segregation were against freedom and human rights. For all of these, the teachers of the ideological and political theory course in colleges and universities must deeply analyze them for the students, uncover the hypocrisy of "Universal Values", solve the students' doubts, and further strengthen the centripetal force of the leadership and governance of the Communist Party of China.

\subsection{Criticize the Trend of Thoughts of anti- Marxism Righteously}

In the theoretical system of the Communist Party of China, the first banner is Marxism. Some people may ask, why is it Marxism instead of other doctrines? In fact, on the stage of modern Chinese history, in order to save the Chinese nation from danger, all kinds of doctrines and ideological trends appeared one after another, but unfortunately, they did not succeed in the end. The reason why the Communist Party of China chose Marxism is the historical necessity and the answer given by the era.

Whether in the 95th anniversary of the founding of the Communist Party of China or the 200th anniversary of the birth of Marx, General Secretary Xi spoke highly of Marxism. "In the human ideological history, there is no theory that has exerted such extensive and great influence on the progress of human civilization as Marxism." ${ }^{[8]}$ Turning over the picture of modern Chinese history, we must affirm the basic fact that the Communist Party of China has found the right revolutionary road and socialist construction road under the guidance of the Marxist theory. Although there were some twists and turns in this process, it has basically completed the historical mission that no other theories or doctrines in history have ever accomplished. In recent years, antiMarxist thoughts have emerged such as the so-called statement that "Marxism is out of date", "Marxism is no longer useful", and even the opinions which emphasize "the guiding ideology should be diversified", which have greatly weakened the theoretical guiding force of Marxism especially for young students. As teachers of the ideological and political theory course, we should stand firm to reveal the essence of various anti-Marxist thoughts to students in time. To test whether an ideological theory or doctrine is "outdated" or "useless", the most fundamental thing is to see whether it has contemporary value. Although Marxism was born more than a century ago, it reveals the law of the development of human society and it is a scientific truth proved by practice. Truth is not and will not be out of date. The brilliant achievements in the construction of socialism with Chinese characteristics in the new era strongly prove the vitality of Marxism in today's society. Similarly, the core idea of Marxism is to seek happiness for a vast majority of people, which will never be useless. Today's changes of the times and profound revolutions are far beyond the imagination of the classical Marxist writers. 
However, no matter how the world develops, the pace of people's pursuit of happiness is always moving forward, and thus Marxism is not outdated but has eternal value.

\section{ACTIVE IMPLEMENTATION TO IMPROVE THE ABILITY OF CRITICISM AND CONSTRUCTION}

Today's China is in the background of a great change that has never occurred in the previous hundreds of years. All kinds of thoughts and doctrines -- mainstream and non-mainstream, positive and negative -- are surging, which coexist at the same time. Whether a teacher of the ideological and political theory course in colleges and universities dares to "show his sword" to all kinds of wrong thoughts in time has become a touchstone to measure whether the teacher adheres to the Marxist position. The faculty of the ideological and political theory course should not only have solid theoretical knowledge, but also have a broad international vision. They need to deal with students' doubts in international comparison and guide them to have a comprehensive and objective understanding of the development and changes of contemporary China.

\subsection{Be Problem-oriented and Carry Forward the Critical Spirit}

Being problem-oriented is a distinctive feature of Marxism. Adhering to being problem-oriented and carrying forward the critical spirit requires, first of all, indepth analysis and research on various problems. The deeper the research is, the more accurate the problems can be found and the more capable we can criticize them. Secondly, the criticism of various wrong views and trends of thought should be able to grasp the key points and be highly targeted. For example, why should we criticize neo-liberalism? Because it will bring a lot of harm to practice. In class, it can be pointed out that neo-liberalism propagates absolute liberalization, complete marketization and privatization. This ideological tendency is not in line with China's basic national conditions and goes contrary to the socialist basic economic system and distribution system. In the meanwhile, the severe consequences of the spread of neoliberalism in Latin America, Russia and some Asian countries are lessons for us.

\subsection{Develop the Sense of Responsibility and Enhance the Critical Ability}

General Secretary Xi Jinping has repeatedly pointed out that teachers in ideological and political education should have a clear sense of responsibility. As a teacher of ideological and political theory course, we should develop dialectical thinking and enhance critical ability. We should not only actively carry forward the positive energy and give full scope to the theme of the times, but also face up to the problems and the wrong trends of thought, so that students can widen their horizons, broaden their thinking and gain the ideological power through the comparison of positive and negative aspects, so as to enhance the attraction of the ideological and political theory course. It is true that over the past 40 years of reform and opening-up, new changes have taken place in China, but at the same time, we should also face up to the problems and shortcomings in the process of socialist construction instead of covering up our weaknesses and being complacent. The teachers of ideological and political theory course should be bold in and good at in-depth analysis of various problems existing in practice, exploring the root causes, essence and development trends of problems, and guiding students to build up a high sense of identity with socialism with Chinese characteristics on the basis of dialectical understanding.

\subsection{Strengthen Theoretical Research and Master Construction Skills}

In addition to telling Chinese stories well and criticizing all kinds of wrong ideas and thoughts, we also need to actively construct correct ones, that is, criticism is for better construction. This requires teachers of ideological and political theory course to have rich and solid theoretical foundation. In the classroom teaching, some teachers lack a solid foundation of the Marxist theory, do not pay attention to the advamces in academic frontiers, and are not always able to respond to international hot spots and topics concerned by students. Such classroom teaching is undoubtedly feeble, and students will feel sleepy in class. As long as the theory is thorough, it can convince people. Facing the ideological characteristics and thirst for knowledge of the students born in the 2000s, responding to various social realities and trends of thought, and mastering the construction skills, the teachers of the ideological and political theory course must strengthen theoretical research. Firstly, we should strengthen the research on the mainstream ideology, enhance the theoretical depth, and give positive responses to all kinds of problems raised by the times. Second, we should strengthen the study of various social ideological trends. In-depth and thorough research enhances the efficiency of criticism. Abstract criticism is far from enough. The criticism and construction of concrete practice is also important. Superficial criticism without hitting home cannot achieve the desired effects and the construction.

\section{CONCLUSION}

The Ideological and political theory course is the unity of constructiveness and criticalness. If it is said that adhering to the constructiveness of the ideological and political theory courses in colleges and universities is to "abide by the right path", then adhering to the criticalness 
is to "block the evil path". ${ }^{[9]}$ To enhance the criticalness of the ideological and political theory course in colleges and universities, in the final analysis, is not to avoid or deny some basic facts, but to guide students to resist the infiltration of Western wrong values, draw a clear line between right and wrong, and correct wrong understanding. It is hoped that the teachers of the ideological and political theory course in colleges and universities can take up the weapon of criticism, carry forward the spirit of criticism, enhance their ability to criticize, and always be ready for great struggles with many new historical characteristics.

\section{FUND PROJECTS}

Quality Engineering Teaching Research Project of Anhui Provincial Department of Education in 2020 (2020szjyxm0700); Domestic Academic Visit Project for Outstanding Young Talents in Colleges and Universities Sponsored by Anhui Provincial Department of Education (gxgnfx2020050); Ideological and Political Work Ability Improvement Project Sponsored by Anhui Provincial Department of Education (sztsjh2019-3-16).

\section{ABOUT THE AUTHOR}

Yu Haiyan (1983 -), female, Han nationality, born in Chaohu, Anhui Province, lecturer in Anhui Vocational and Technical College, majoring in ideological and political education.

\section{REFERENCES}

[1] Xi Jinping: With the Socialist Ideology of Socialism with Chinese Characteristics and Soul Education, Carry out the Party's Educational Policy and Implement the Basic Task of Moral Education and Talent Cultivation. People's Daily March $19^{\text {th }}, 2019$.

[2] Xi Jinping: The Governance of China (Volume 2) [M]. Beijing: Foreign Languages Press, 2017.

[3] [4] Collected Works of Mao Zedong (Volume 3) [M]. Beijing: People's Publishing House, 1999.

[5] [6] Selected Works of Deng Xiaoping (Volume 2) [M]. Beijing: People's Publishing House, 1994.

[7] Xi Jinping: Raise the Banner of the People, Cultivate the New Culture and Promote the Cultural Exhibition to Better Fulfill the Mission of Propaganda and Ideological work under the New Situation. People's Daily, August 23 ${ }^{\text {rd }}, 2018$.

[8] Xi Jinping: Speech at the Symposium on Philosophy and Social Sciences (Full Text) [EB/OL] http://politics.people.com.cn/n1/2016/0518/c102428361421-2.html.

[9] Zhao Chuanhai. Necessity of Enhancing the Crticalness of the Ideological and Political Theory
Course [J]. Journal of Shangqiu Norma University, 2019 (11). 